\title{
Use of the TEM Cell for Compliance Testing of Emissions and IEC Perspective
}

\section{Bentz, Sigurd}

Published in:

IEEE 1996 International Symposium on Electromagnetic Compatibility

Link to article, DOI:

10.1109/ISEMC.1996.561198

Publication date:

1996

Document Version

Publisher's PDF, also known as Version of record

Link back to DTU Orbit

Citation (APA):

Bentz, S. (1996). Use of the TEM Cell for Compliance Testing of Emissions and Immunity, an IEC Perspective. In IEEE 1996 International Symposium on Electromagnetic Compatibility (pp. 43-47). IEEE. https://doi.org/10.1109/ISEMC.1996.561198

\section{General rights}

Copyright and moral rights for the publications made accessible in the public portal are retained by the authors and/or other copyright owners and it is a condition of accessing publications that users recognise and abide by the legal requirements associated with these rights.

- Users may download and print one copy of any publication from the public portal for the purpose of private study or research.

- You may not further distribute the material or use it for any profit-making activity or commercial gain

- You may freely distribute the URL identifying the publication in the public portal 


\title{
Use of the TEM Cell for Compliance Testing of Emissions and Immunity, an IEC Perspective
}

\author{
Sigurd Bentz \\ Technical University of Denmark \\ DK-2800 Lyngby, Denmark
}

\begin{abstract}
The current work of IEC on preparing a standard for the use of TEM cells for compliance testing of emissions and immunity is reviewed. Requirements to TEM cells are related to the established procedures: "Open area test site" and "shielded enclosure with area of uniform field", respectively The problems of incorporating new technology into standardization as well as the existence of parallel standardized test procedures are discussed.
\end{abstract}

\section{ELECTROTECHNICAL STANDARDIZATION}

The international standardization movement is organised in e.g. IEC, the International Electrotechnical Commission. The objective for standardization is expressed by IEC as "dedicated to the global harmonization and voluntary adoption of standards in the interests of society in general, supporting the transfer of electrotechnology, assisting certification and promoting international trade". This is accomplished by "developing consensus global standards in the electrotechnical field" [1].

"IEC standards are widely adopted as the basis of national or regional electrotechnical standards. For example, more than 90 per cent of the electrotechnical European Standards (EN) harmonized by CENELEC and adopted in the countries of the European Union and the European Free Trade Area are either identical with or very closely based on IEC international standards" [1]

In this way the international voluntarily adopted standards find their way to legal requirements on a national or regional level. This challenges the standardization bodies to write standards, which are able to gain broad acceptance as fair, balanced and worthwhile.

\section{IMPACT OF STANDARDIZATION ON EMC}

For the EMC community standardization is important for $i$. a

- test and measurement methodology,

- test and measurement equipment,

- emissions and immunity levels.

Standardization of immunity test or emissions measurement procedures is beneficial for the EMC community. The standardized procedures are agreed upon by consensus of all interested parties as the best possible choice. The procedures are considered repeatable, reproducible, accurate and valid [2].
Repeatability is agreement between the results of successive measurements carried out under the same conditions, whereas reproducibility is agreement between the results of measurements carried out under changed conditions. Considering compliance testing it is extremely important that a test within an acceptable uncertainty gives the same result from test site to test site, from person to person and from time to time.

The accuracy is the closeness of the agreement between the results of a measurement and a true value of the mesurand. Accuracy depends partly on the quality of the equipment, and partly on the skill of the operator. In a GO/NOGO decision as in compliance testing the accuracy is vital

The validity of an EMC immunity test procedure plays a peculiar role. Except for the Swedish spark test [3] it is only a second priority to define a test procedure, which is a true replica of the real world. Repeatability, reproducibility and accuracy has been given the first priority. The validity of an immunity test method is then considered sufficient, if an apparatus, which fails due to real world electromagnetic interference with a reasonable probability will fail during the test and - vice versa - if an apparatus, which is immune to real world electromagnetic disturbances with a high probability will not fail during the test.

Standardization of test and measurement procedures will limit the number of different test setups and thus limit the time consumption for testing. Fewer different types of equipment will be needed, and they will be available for all users. Furthermore tests and measurements will be more reproducible, if everybody uses similar kinds of equipment

The draw back of standardization on EMC test and measurement is conservatism. Once a procedure or an equipment has been standardized, the situation is frozen. Manufacturers don't have a market for new products, users are reluctant to invest in new equipment. The impetus which is necessary to gain broad acceptance of a new procedure - in the EMC community in general and especially in the standardization bodies - is hard to support by manpower and funding because of the uncertainty involved and the long time horizon for a return of the investments. The investment in existing equipment has also to be considered. Standardization can thus be seen as a barrier against the introduction of new technology

Another interesting aspect rises if a new procedure for compliance testing will be a substitute of a well established one. In the case of dispute, will one procedure take precedence? Can product committees or manufacturers freely choose the procedure they prefer? Should each procedure have its own area of use? This aspect will be discussed later in this paper. 


\section{INTRODUCING TEM CELLS}

IEC has in 1994 accepted a new work item proposal from the National Committee of Switzerland on the standardization of requirements for TEM cells and related procedures for immunity testing and emissions measurements for frequencies up to $5 \mathrm{GHz}$ $[4,5]$. A Committee Draft [6] was circulated for comments until September 1995 and for further discussion at the IEC Technical Committee 77 meeting at Durban, October 1995. This first committee draft has been prepared by the project leader nominated for this project. No working group has been set up to undertake this task.

The title for the anticipated standard is "IEC 1000-4-20: Electromagnetic Compatibility (EMC) - Part 4: Testing and measurement techniques. Section 20: TEM cells. Basic EMC Publication". This work is in many aspects analogous to the work accomplished by FCC in 1993 [7].

At the time of writing no Collation of Comments nor minutes from the Durban meeting have been received. At the Santa Clara IEEE 1996 Symposium on EMC the latest development will be taken into account. This paper has been prepared as seen from the side line. The author has as a member of the Danish National Committee and an appointed member of the working group to be formed followed the current discussion with greatest interest.

\section{TEM CELL CHARACTERISTICS}

A TEM cell or a Transverse ElectroMagnetic cell is essentially a rectangular, two conductor, $50 \Omega$ transmission line with a closed outer conductor. It is often called "coaxial", but this term is misleading. A TEM cell has no axis of symmetry

The dimensions of a TEM cell are made so big, that there is a volume between the inner conductor - called the septum - and the outer conductor, sufficient for the placement of an EUT, an equipment under test.

There are two families of TEM cells. The dual port TEM cell - also called a Crawford cell or just a TEM cell - has an input/output measurement port at each end. The middle section could be a cube. The two tapered end sections adapt the middle section to conventional $50 \Omega$ coaxial connectors at the ports [8].

Dual port TEM cells have a limited band width determined by the generation of higher order modes in the field. The band width is inverse proportional to the dimension of the cross section. Usually the band width is well below $1000 \mathrm{MHz}$, which means, that a dual port TEM cell only will cover a part of the frequency range of interest for EMC test and measurement.

The single port TEM cell, the wide band TEM cell or the broad band TEM cell has a single input/output measurement port with a conventional $50 \Omega$ coaxial connector. It has the shape of a lying pyramid with a rectangular base and the input/output port at the vertex. Such TEM cells feature a broad band line termination at the end opposite the measurement port. This termination combines a low frequency lumped load, which matches the characteristic impedance of the TEM cell, with a high frequency absorptive wall of anechoic material.

The most well known single port TEM cell - with far the most widespread use - is the GTEM cell, which is patented by ABB, Switzerland $[9,10]$ and manufactured under license by several manufacturers worldwide

The most interesting feature of a single port TEM cell is, that because of its regular shape there is no inherent cause for a limitation of the band width, as we found it in the dual port TEM cell. Depending on the quality of manufacturing and workmanship, the frequency range is supposed to go high up in the $\mathrm{GHz}$ range.

Common for both families of TEM cells is, that they have limitations in the size of equipment, which can be accommodated in a volume of the TEM cell with uniform field.

\section{IMMUNITY TESTING ACCORDING TO IEC 1000-4-3}

IEC 1000-4-3 [11] is a basic EMC standard. Its object is to establish a common reference for evaluating the performance of electrical and electronic equipment when subjected to radio frequency electromagnetic fields

Because of the magnitude of the field strengths generated, the test shall be made in a shielded enclosure in order to comply with various national and international laws prohibiting interference to radio communications. The preferred test facility consists of an absorber-lined shielded enclosure that shall be large enough to accommodate the EUT whilst allowing adequate control over the field strengths.

The field is generated by a linearly polarized broad band antenna as a biconical or logperiodic antenna. It shall be placed at a distance sufficient to allow a calibration area to fall within the beam width of the transmitted field. A distance of $3 \mathrm{~m}$ between antenna and EUT is preferred.

The test field is swept from $80 \mathrm{MHz}$ to $1000 \mathrm{MHz}$ with the signal $80 \%$ amplitude modulated with a $1 \mathrm{kHz}$ sinewave.

IEC 1000-4-3 is tolerant towards other procedures A note explains, that alternative methods of generating EM fields include TEM cells etc. Care should be taken to ensure that the conditions of test are equivalent to those in the anechoic chamber.

Three questions are of special interest when comparing the IEC 1000-4-3 procedure with a test in a TEM cell

Calibration of field.

Arrangement of wiring

Orientation and Polarization. 
IEC 1000-4-3 uses the concept of a uniform area, which is a hypothetical vertical plane of the field in which variations are acceptably small. This uniform area is $1.5 \mathrm{~m} \times 1.5 \mathrm{~m}$, unless the EUT and its wires can be fully illuminated within a smaller surface. The field is calibrated in an empty test site and with a unmodulated wave.

A field is considered uniform if its magnitude over the defined area is within $-0 \mathrm{~dB}$ to $+6 \mathrm{~dB}$ of nominal value in at least 12 of the 16 points measured. An amendment is proposed by UK to improve the uniformity of the test site [12].

Wiring is left exposed to the electromagnetic field for a distance of $1 \mathrm{~m}$ from the EUT. Longer wires are bundled low inductively to $1 \mathrm{~m}$ length. The bundled length of exposed wiring is run in a configuration which essentially simulates normal wiring. That is, the wiring is run to the side of the EUT, then either up or down as specified in the installation instructions. The horizontal/vertical arrangement helps to ensure worst case conditions.

The test shall normally be performed with the generating antenna facing each of the four sides of the EUT. When equipment can be used either vertical or horizontal, the test shall be performed on all sides. The 4 resp. 6 tests are made with vertical and horizontal polarization

\section{IMMUNITY TESTING IN TEM CELLS}

If a TEM cell is connected to a generator, it acts at one time as a field generating antenna and as anechoic enclosure

When the IEC 1000-4-3 requirements are transferred into equivalent requirements on the calibration and use of a TEM cell, the following considerations apply.

Few TEM cells are big enough to accommodate a $1.5 \mathrm{~m} \times 1.5$ $\mathrm{m}$ calibration area. The field is generated between the septum and the outer conductor, so it is essentially vertically polarized. Because of the fixed structure, the field non-uniformity is partly known, and it is not dependent on the test setup. A field uniformity area of $1.5 \mathrm{~m} \times 1.5 \mathrm{~m}$ is of these reasons neither necessary nor possible. The IEC 1000-4-3 statement quoted in the previous section: "unless the EUT and its wires can be fully illuminated within a smaller surface" should be applied to TEM cells.

For a given cell a maximum useful volume is defined. The background for this is the loading of the cell by the EUT. Traditionally this is considered to be $1 / 3$ of the distance between septum and outer conductor $x 1 / 3$ of the cell width. Recent claims by manufacturers, that this could be augmented to $1 / 2 \times 1 / 2$ need further investigation before it is broadly accepted.

An area equal to the cross section of the useful volume should be the area of uniform field. This area is usually much less than $1.5 \mathrm{~m} \times 1.5 \mathrm{~m}$. If the number of 16 measurement points is maintained, the spacing between them will be smaller than the $0.5 \mathrm{~m}$ required in IEC 1000-4-3. The uniformity requirements to the TEM cell would thus be higher. It could be argued, that the smaller area as well as the symmetry and the inherent and partly known non-uniformity of the TEM cell field could justify the use of a smaller number of measurement points. This is a point which needs further investigation. The tolerance of $-0 /+6$ $\mathrm{dB}$ in $75 \%$ of measurement points should be maintained

In an anechoic enclosure the field uniformity depends on the test setup, so it needs calibration with short intervals. In TEM cells, the test setup doesn't change. The interval between calibrations should be substantially longer in a TEM cell.

Further more, as a transmission line the field uniformity in a TEM cell is closely related to the transmission characteristics. Standard transmission line measurements as voltage standing wave ratio (VSWR) or time domain reflectometer (TDR) measurements should be an excellent check on the field uniformity, once the TEM cell has been calibrated.

Concerning the arrangement of wires as well as orientation and polarization, the space limitations of TEM cells are a serious hindrance. Procedures should be defined for positioning of the EUT in a TEM cell, so that tests in TEM cells and anechoic enclosures are closely related.

The fields generated in a TEM cell or of an antenna in an anechoic enclosure are not identical. Especially under loading conditions the characteristics may differ. This is considered as a minor problem, in accordance with the stated tolerance of IEC 1000-4-3: "Alternative methods of generation EM fieids include TEM cells etc. "

There is an obvious need for comparative measurements. The international EMC community should invest a fair deal of efforts in order to gain a deeper understanding of these issues.

\section{EMISSIONS MEASUREMENTS ACCORDING TO CISPR 22}

CISPR 22 [13] is a product family standard for RF emissions from information technology equipment (ITE). Nevertheless it is considered - and used extensively - as a basic standard for RF emissions measurements. Procedures are given for the measurement of the levels of spurious signals generated by the ITE.

For radiated emissions (RE) measurements CISPR 22 requires an open area test site (OATS) with an antenna to EUT distance of $10 \mathrm{~m}$. The test site shall be provided with a horizontal metal ground plane. A test site is qualified by a so-called "site attenuation measurement". This procedure has no parallel in a TEM cell.

The receiving antenna is a balanced dipole. The antenna-toground distance shall be adjusted between $1 \mathrm{~m}$ and $4 \mathrm{~m}$ and the EUT shall be rotated in order to find the maximum field strength. Measurements are made with horizontal as well as vertical polarization. 
According to CISPR 22 the horizontal and vertical component of the electrical field strength is measured in the far field. The measured field is a superposition of the direct wave and the reflected wave from the ground plane. The measurement procedure is essentially a search for the point with maximum field strength. The field is only measured to the sides of the EUT, but not vertically above or below the EUT

CISPR 22 has a clause on "Alternative test sites", but here the TEM cell is definitely not included.

\section{EMISSIONS MEASUREMENTS IN TEM CELLS}

If an EUT is placed inside a TEM cell, the emitted field couples into the transmitting modes of the TEM cell field, and is thus led to the output terminal(s) of the cell. The TEM cell can be considered as a combination of a transmission line and a receiving antenna.

The great advantage of the TEM cell is, that it is in itself a shielded enclosure. The ambient noise coming from emitters of all kinds, which is the big problem for an OATS - especially close to big cities - is usually attenuated by the TEM cell itself to a level below the noise floor of the equipment. The drawback of the TEM cell is - like for immunity testing - the limitations in the size of equipment, which can be accommodated.

The measurement principles are different on an OATS and in a TEM cell. Measurements on an OATS are performed in the far field. In most of the frequency range a TEM cell couples with (what traditionally is called) the near field of the EUT.

The coupling between the EUT and the TEM cell give the emitter a radiation characteristic, which is different from that in free space or on an OATS with ground plane. Thus the emitted field from an EUT is different in the three cases. For small EUTs this difference can be neglected.

On an OATS the maximum electric field strength is measured. TEM cells measure basically the power transmitted to the output port. The higher order modes influence the field coupling in a TEM cell in a complicated way. This is not easily accounted for by the evaluation of the measured power

In the cases, where an EUT has a high directivity - which means that the emitted field is concentrated in a certain direction - it is not a simple matter to get a true pick up of this field. Even for unintentional emitters a high directivity is often found at frequencies in the $\mathrm{GHz}$ range. A manufacturer claims to have solved this problem, but the procedure is not publicly known.

\section{The Dilemma of Parallel Test Principles}

For the time being the interest is totally focussed on the CISPR 22 OATS procedure. This means that a great deal of effort are devoted to make correlations between OATS and TEM cell measurements.
The idea is, that the power measured in the TEM cell is considered to come from a short dipole source. This is a reasonable assumption, when spurious emissions have a similar directivity. With the measured power as input, a software package is used to simulate the OATS measurements according to CISPR 22 specifications

The claim from the standardization bodies as well as the EMC community at large is, that it is documented that there is a statistical agreement between OATS measurements and TEM cell measurements including the correlation algorithm. This has to be shown for every group of EUT's. This is the approach taken by FCC, and it is probably the approach IEC will take.

This leaves open to the manufacturers to choose which procedure they want to follow in positioning the EUT during measurements in the TEM cell. It further allows them to make their own correlation algorithm.

Even if this claim is only partly fulfilled, TEM cells have still a great potential for precompliance testing, if their results are close to the final OATS compliance measurements.

Another approach could come out of the claim, that TEM cell measurements - like OATS measurements - have a value in their own right. Then one standard should give the field strength limits as measured on an OATS according to CISPR 22. An alternative standard should give the power limits measured in a TEM cell. No correlation is needed between the two types of emission limits.

One way to handle this could be to make sure, that the severity of the two sets of limits are almost equal. This should be shown in a round robin involving many test labs in many countries and many different types of EUT's. A totally fair treatment of manufacturers / products / test labs is maybe a greater burden, than to have unfair tests, which are easy to perform

This procedure could be followed by a recommendation to product standardization committees to choose just one of the procedures in their product EMC standards.

Another way to proceed is to accept a new technology - i.a TEM cells - as a useful new development in EMC measurement techniques. The standard should allow no overlap between different procedures. This means that small EUT's should be measured in a TEM cell and big EUT's should be measured on an OATS.

A consequent use of this principle could for illustration purposes be found in the former Danish LF immunity standard [14] using the following rule for the maximum dimensions of an EUT 


$$
\begin{array}{ll}
0.25 \mathrm{~m} \times 0.25 \mathrm{~m} \times 0.25 \mathrm{~m}: & \text { Strip line } \\
0.8 \mathrm{~m} \times 0.8 \mathrm{~m} \times 0.8 \mathrm{~m}: & \text { Fields Plates } \\
2 \mathrm{~m} \times 2 \mathrm{~m} \times 2 \mathrm{~m}: & \text { Longwire Antenna } \\
2 \mathrm{~m} \times 2 \mathrm{~m} \times 2 \mathrm{~m}+: & \text { Individual negotiations }
\end{array}
$$

In order to keep EMC testing and measurements in the front line of the technological development a procedure should be found to handle problems like this. Personally the author could imagine that a solution like the one outlined here will be in common use early in the next century.

\section{CONCLUSIONS}

It is the responsibility of the standardization bodies to write standards, which are able to gain broad acceptance as fair, balanced and worthwhile. Further they have the responsibility continually to include new procedures and new technology into the standards, as soon as they are recognized as mature. This is the only way to serve the EMC community with state-of-the-art procedures.

The prerequisite for this sound development is continually experimentation with new procedures and new technology. This should be done systematically and in a broad international forum.

\section{ACKNOWLEDGMENTS}

The author wishes to thank his former student, Lilla $G$. Monrad, TELECOM DENMARK Ltd., and a colleague, Jan Petersen, Odense Engineering College, for their valuable suggestions.

\section{REFERENCES}

[1] 1995 Catalogue of IEC Publications. 1995, p. 4.

[2] Guide to the Expression of Uncertainty in Measurement. Geneva: ISO, 1993.

[3] Elektronikutrustningar för industri och handel, Tålighet mot ledningsbundna elektriska störningar. SS 4361503. Stockholm: SEK, 1986.

[4] New Work Item Proposal. IEC 77B(CH)3. Sept. 1993

[5] IEC 77B(SEC) 135.

[6] Committee Draft. IEC 77B/153/CD. June 1995.

[7] FCC will accept GTEM Measurement Data Under Limited Conditions. FCC Public Notice, December 2, 1993

[8] M. L. Crawford and J. L. Workman, Using a TEM Cell for EMC Measurements of Electronic Equipment. Nat. Bureau of Standards, NBS Technical Note 1013, 1981.

[9] D. Königstein and D. Hansen, "A new family of TEM-cells with enlarged bandwidth and optimized working volume", in Proc. 7th Int. Zurich Symp. and Techn. Exh. on $E M C, 1987$, pp. 127-132.

[10] D. Hansen and D. Königstein, Device for EMI Testing of Electronic Systems. US Patent Office, US 4.837.581. June 6, 1989. D. Hansen und D. Königstein, Vorrichtung zur EMI-Prüfung elektronischer Geräte. Europäisches Patentamt, EP O 246544 B1, Sept. 5. 1990.

[11] Electromagnetic Compatibility (EMC)

Part 4: Testing and measurement techniques Section 3: Radiated, radio-frequency, electromagnetic field immunity test. IEC 1000-4-3:1995. Geneva: IEC, 1995.

[12] Report of the activities of 77A/WG 6: LF immunity tests and 77B/WG3: HF Immunity tests. 77B/162/INF. Geneva: IEC, September 8, 1995.

[13] Limits and methods of measurement of radio disturbance characteristics of information technology equipment. CISPR 22:1993, Geneva: IEC, 1993.

[14] Elektrisk og magnetisk emission og immunitet af elektronisk udstyr i frekvensområdet $50 \mathrm{~Hz}-150 \mathrm{kHz}$. DS 5105. Copenhagen: Danish Standards Ass. 1987. 